\title{
Radical chain reactions in pyrolytic cleavage of the ether linkages of lignin model dimers and a trimer
}

\section{AUTHOR(S):}

Watanabe, Toshihiro; Kawamoto, Haruo; Saka, Shiro

\section{CITATION:}

Watanabe, Toshihiro ... [et al]. Radical chain reactions in pyrolytic cleavage of the ether linkages of lignin model dimers and a trimer. Holzforschung 2009, 63(4): 424-430

\section{ISSUE DATE:}

2009-07-01

URL:

http://hdl.handle.net/2433/240652

\section{RIGHT:}

(c) by Walter de Gruyter $\bullet$ Berlin $•$ New York.; The full-text file will be made open to the public on 1 July 2010 in accordance with publisher's 'Terms and Conditions for Self-Archiving'. 


\section{Radical chain reactions in pyrolytic cleavage of the ether linkages of lignin model dimers and a trimer}

\section{Toshihiro Watanabe, Haruo Kawamoto* and Shiro Saka}

Graduate School of Energy Science, Kyoto University, Yoshida-honmachi, Sakyo-ku, Kyoto, Japan

${ }^{*}$ Corresponding author.

Graduate School of Energy Science, Kyoto University, Yoshida-honmachi, Sakyo-ku, Kyoto 606-8501, Japan Phone/Fax: + 81-75-753-4737

E-mail: kawamoto@energy.kyoto-u.ac.jp

\begin{abstract}
$\beta$-Ether-type dimers, [1-(4-hydroxy-3-methoxyphenyl)-2(2-methoxyphenoxy)-1-propanol and 1-(3,4-dimethoxyphenyl)-2-(2-methoxyphenoxy)-1-propanol], and an $\alpha, \beta$-diether-type trimer [1-(4-(3,4-dimethoxybenzyloxy)3-methoxyphenyl)-2-(2-methoxyphenoxy)-1-propanol] were pyrolyzed in a closed ampoule reactor $\left(\mathrm{N}_{2} /\right.$ $\left.250-400^{\circ} \mathrm{C} / 2 \mathrm{~min}\right)$. 1-Phenylpropenes $\left(\mathrm{C}_{\alpha}=\mathrm{C}_{\beta}\right)$ and 1phenylpropanones $\left(C_{\alpha}=O\right)$ were obtained as the major $\beta$-ether-cleaved products. Radical chain mechanisms are proposed in which hydrogen abstraction at the phenolic $\mathrm{O}-\underline{\mathrm{H}}$ and $\mathrm{C}_{\alpha}-\underline{H} \mathrm{~s}$ occurs, respectively. The former reaction which gives rise to three radical species was much more effective than the latter. As the effective reaction increases the radical concentration, cleavage of the $\beta$-ether linkage in the phenolic dimer is achieved at a much lower temperature $\left(260^{\circ} \mathrm{C}\right)$ than that of the non-phenolic type $\left(360^{\circ} \mathrm{C}\right)$. Radical chain reactions are initiated in the case of the trimer with a weak $\mathrm{C}_{\alpha}-\mathrm{O}$ bond at lower temperature $\left(320^{\circ} \mathrm{C}\right)$ than those of the non-phenolic (methylated) dimer, since homolysis of the $\mathrm{C}_{\alpha}-\mathrm{O}$ bond produces the phenoxy type dimer and 3,4-dimethoxybenzyl radicals as initiators. However, some of the dimer phenoxyl radical was stabilized by $\mathrm{H}$-abstraction (to form dimer) or by recombination with a 3,4-dimethoxybenzyl radical (to form C-benzylated products) so that the chain depolymerization via quinone methide intermediate was suppressed.
\end{abstract}

Keywords: $\alpha$-ether; $\beta$-ether; hydrogen abstraction; lignin; pyrolysis; radical chain reaction.

\section{Introduction}

Thermogravimetric (TG) studies have shown that main volatilization of lignin samples occurs between $200^{\circ} \mathrm{C}$ and $500^{\circ} \mathrm{C}$ with DTG peaks around $300-400^{\circ} \mathrm{C}$ (Fenner and Lephardt 1981; Gardner et al. 1985; Haw and Schultz 1985; Jakab et al. 1997). Lignin ether linkages ( $\alpha$ - and $\beta$-ether types linkages) are cleaved and contribute to depolymerization (volatilization) of lignin (Haw and Schultz 1985; Nakamura et al. 2008). Accordingly, the corresponding reactions have been studied extensively, especially those of the $\beta$-ether cleavage, which is the most abundant linkage-type in lignin (Klein and Virk 1983; Brežný et al. 1983, 1984; Autrey et al. 1991; Britt et al. 1995; Kawamoto et al. 2007a,b, 2008a,b). In many papers, the cleavage mechanisms of model dimers and trimers are discussed. It is well known that phenolic dimers are generally much more reactive than the corresponding non-phenolic ones (Brežný et al. 1983, 1984; Kawamoto et al. 2007a,b, 2008a,b; Nakamura et al. 2008). Thus, the cleavage mechanisms are also influenced by structural details.

Kawamoto et al. (2008a) proposed that higher reactivities of the phenolic dimers are related to the heterolysis reactions which proceed only in phenolic units. These authors discussed the cleavage mechanism (heterolysis vs. homolysis) of dimers and trimers depending on the substituent effects of the $p$-substituents $\left(-\mathrm{OCH}_{3}, \mathrm{H}, \mathrm{Cl}\right.$, and $\mathrm{COCH}_{3}$ ) and the Hammett's $\sigma_{p}$ or $\triangle \mathrm{BDE}$ (bond dissociation energy) parameters were taken into consideration. According to their conclusions, the $\mathrm{C}_{\alpha}$-OR bonds in phenolic units are cleaved heterolytically assisted by electron donation from the oxygen lone pairs of the phenolic $p-O H s$. This reaction gives quinone methide intermediates. Contrary to this, the $\alpha$-ether linkages in non-phenolic units are cleaved homolytically to form benzyl radical intermediates, and this type of reaction requires much higher pyrolysis temperature around $350^{\circ} \mathrm{C}$. As for the $\beta$-ether linkage, homolysis temperature of the $\mathrm{C}_{\beta}-\mathrm{O}$ bonds in the phenolic unit was lowered by $100-150^{\circ} \mathrm{C}$ via quinone methide intermediate, although the $\mathrm{C}_{\beta}-\mathrm{O}$ bonds in both phenolic and non-phenolic units are cleaved homolytically.

Elimination of the $\mathrm{C}_{\gamma}-\mathrm{OH}$ from guaiacylglycerol- $\beta$ guaiacyl ether reduced the reactivity of the $\mathrm{C}_{\beta}-\mathrm{O}$ bond cleavage down to the level of the non-phenolic (methylated) dimer (Kawamoto et al. 2007b). This finding is quite remarkable since the $\mathrm{C}_{\gamma}-\mathrm{OH}$ is not directly involved in the quinone methide-forming reaction. From the reactivities of the regiospecifically deoxygenated (Kawamoto et al. 2007b) and methylated (Kawamoto and Saka 2007) derivatives of guaiacylglycerol- $\beta$-guaiacyl ether it was proposed that the $\mathrm{C}_{\gamma}-\mathrm{OH}$ in the heterolytic quinone methide formation plays a role as stabilizer of the transient state in which an intramolecular hydrogen bonding exists between the $\mathrm{C}_{\alpha}$ - and $\mathrm{C}_{\gamma}$-OHs. Based on this information, it can be suggested that heterolysis of the $\mathrm{C}_{\alpha}$-OR bonds in lignin is highly dependent on the threedimensional structure of lignin, especially on that of the side chain.

Alternatively, radical chain mechanisms have been reported for phenethyl-phenyl ether and its derivatives (Autrey et al. 1991; Britt et al. 1995; Beste et al. 2007). Radical chain reactions are also indicated for 1-(4hydroxy-3-methoxyphenyl)-2-aryloxy-1-propanols $\left(\mathrm{C}_{\gamma^{-}}\right.$ 
deoxy type dimers). Kawamoto et al. (2008b) reported that the cleavage reactivities increased substantially in a sealed reactor at $400^{\circ} \mathrm{C}$, contrary to findings in an opentop reactor in which the initial compounds were recovered almost quantitatively. In the presence of tetralin (a radical scavenger), the cleavage reaction was strongly inhibited. Thus, the authors concluded that low-molecular weight radicals formed through homolysis of the $\mathrm{C}_{\beta}-\mathrm{O}$ bonds initiate the chain reactions, but the details of the reaction were not discussed.

The $\mathrm{C}_{\alpha}-\mathrm{O}$ bond homolysis, which occurs at approximately $50-100^{\circ} \mathrm{C}$ lower temperature than that of the $\mathrm{C}_{\beta}$ O bond (Nakamura et al. 2008; Kawamoto et al. 2008a), forms the phenoxy type dimer and 3,4-dimethoxybenzyl radicals. Nakamura et al. (2008) have reported that the depolymerization temperature $\left(300-350^{\circ} \mathrm{C}\right)$ of Japanese cedar (Cryptomeria japonica) milled wood lignin (MWL) was close to the homolysis temperature of the $\mathrm{C}_{\alpha}-\mathrm{O}$ bond in non-phenolic $\alpha$-ether type dimer.

In the present paper, the behavior of products formed by ether cleavage during pyrolysis of $\beta$-ether dimers (of $\mathrm{C}_{\gamma}$-deoxy types) are studied in a closed ampoule reactor, to obtain more information about the radical chain reactions. An $\alpha, \beta$-diether type trimer, 1-(4-(3,4-dimethoxybenzyloxy) -3-methoxyphenyl) -2-(2-methoxyphenoxy)-1propanol, is also studied to observe the influence of the weak $\mathrm{C}_{\alpha}-\mathrm{O}$ bond on the chain reactions. The aim of the study was to gain more insight into the reaction mechanisms of ether cleavage in lignins.

\section{Materials and methods}

Preparative thin-layer chromatography (PTLC) was conducted on silica gel plate (Kieselgel $60 \mathrm{~F}_{254}$, Merck) with the solvent system: ethyl acetate/n-hexane or methanol/chloroform. High performance liquid chromatography (HPLC) was carried out with a Shimadzu LC-10A under the following chromatographic conditions: column STR ODS-II, flow rate $0.7 \mathrm{ml} \mathrm{min}^{-1}$, eluent $\mathrm{MeOH} /$ $\mathrm{H}_{2} \mathrm{O}=30 / 70 \rightarrow 100 / 0(0 \rightarrow 40 \mathrm{~min}), 100 / 0(40 \rightarrow 50 \mathrm{~min})$, detector $\mathrm{UV}_{280 \mathrm{~nm}}$, column temperature $40^{\circ} \mathrm{C}$. Nuclear magnetic resonance (NMR) spectra were recorded in $\mathrm{CDCl}_{3}$ with a Varian $\mathrm{AC}-400$ $(400 \mathrm{MHz})$ spectrometer using tetramethylsilane as an internal standard. Chemical shifts and coupling constants are presented as $\delta$ and $J(\mathrm{~Hz})$ values, respectively. The bond dissociation energy (BDE) was calculated under AM1, B3LYP/6-311G* level with a software "Spartan". Zero-point corrections for the BDE's were not made.

\section{Model compounds}

$\beta$-Ether-type dimers, 1-(4-hydroxy-3-methoxyphenyl)-2-(2methoxyphenoxy)-1-propanol (1) and 1-(3,4-dimethoxyphenyl)2-(2-methoxyphenoxy)-1-propanol (2) (Figure 1) were prepared by reduction of the corresponding $\mathrm{C}_{\alpha}=\mathrm{O}$ derivatives with $\mathrm{NaBH}_{4}$ in dioxane (Kawamoto et al. 2008b). This reduction proceeded stereoselectively and gave the erythro-rich mixtures, which were further separated with PTLC to yield pure erythro isomers. Their structures were identified with ${ }^{1} \mathrm{H}$ NMR spectra compared to those in the literature.

An $\alpha, \beta$-diether type trimer, 1-(4-(3,4-dimethoxybenzyloxy)-3methoxyphenyl)-2-(2-methoxyphenoxy)-1-propanol (3) was prepared via the coupling reaction between 3,4-dimethoxybenzyl bromide and 1-(4-hydroxy-3-methoxyphenyl)-2-(2-methoxyphenoxy)-1-propanone (66\% yield) as shown in the synthetic route (Figure 1). Finally, the $\mathrm{NaBH}_{4}$ reduction in dioxane, which also

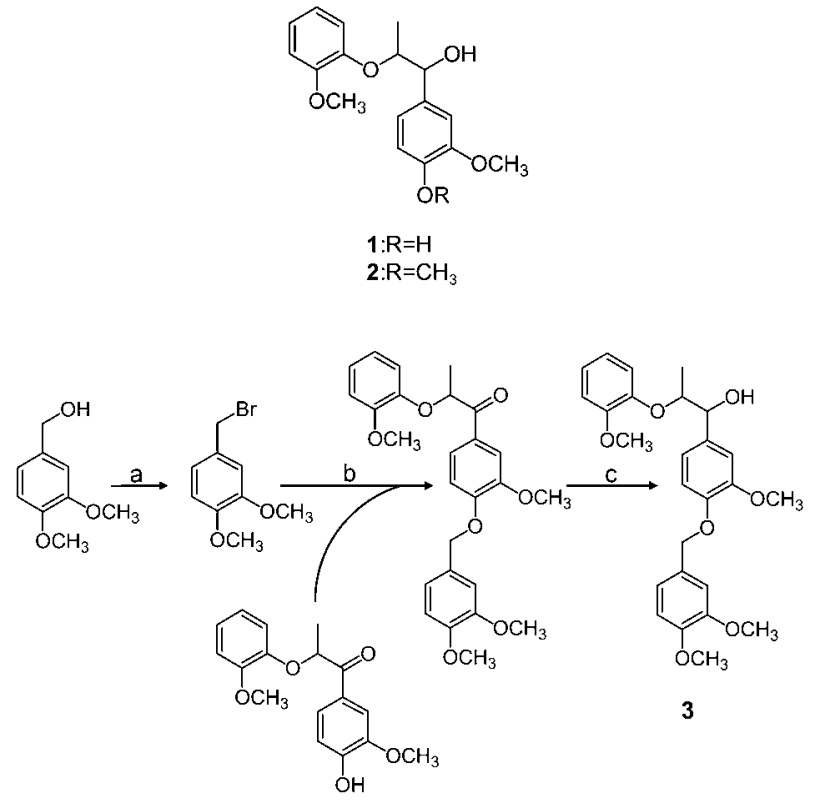

a. $\mathrm{HBr} / \mathrm{CHCl}_{3} / \mathrm{r} . \mathrm{t} / 1.5 \mathrm{~h} / 70 \%$, b. $\mathrm{K}_{2} \mathrm{CO}_{3} / \mathrm{DMF} / \mathrm{r} . \mathrm{t} / 1 \mathrm{~h} / 66 \%$, c. $\mathrm{NaBH}_{4} /$ dioxane/r.t/1.5 h/quantitative.

Figure 1 Model dimers and a trimer.

proceeded stereoselectively, gave trimer 3 (only erythro isomer) quantitatively.

1- (4-(3,4-Dimethoxybenzyloxy) -3-methoxyphenyl)-2-(2-methoxyphenoxy)-1-propanone ${ }^{1} \mathrm{H}$ NMR $\left(\mathrm{CDCl}_{3}\right) 1.71$ (d, $J=6.8$, $\left.3 \mathrm{H}, \mathrm{C}_{\gamma}-\mathrm{H}\right), 3.83\left(\mathrm{~s}, 3 \mathrm{H},-\mathrm{OCH}_{3}\right), 3.88\left(\mathrm{~s}, 6 \mathrm{H},-\mathrm{OCH}_{3} \times 2\right), 3.91(\mathrm{~s}$, $\left.3 \mathrm{H},-\mathrm{OCH}_{3}\right), 5.15$ (s, $2 \mathrm{H}$, arom. $-\mathrm{CH}_{2}-\mathrm{O}$ ), 5.41 (q, $J=6.8,1 \mathrm{H}, \mathrm{C}_{\beta}-$ $\mathrm{H}), 6.7-7.0(\mathrm{~m}, 8 \mathrm{H}$, arom. H), $7.69(\mathrm{~d}, J=2.0,1 \mathrm{H}$, arom. $\mathrm{H}), 7.75$ (dd, $J=2.0,8.4,1 \mathrm{H}$, arom. $\mathrm{H}) ;{ }^{13} \mathrm{C}$ NMR $\left(\mathrm{CDCl}_{3}\right) 19.2\left(\mathrm{C}_{\gamma}\right), 55.9$, 55.9, 55.9, $56.0\left(\mathrm{OCH}_{3}\right), 70.9$ (arom. $\left.-\mathrm{CH}_{2}-\mathrm{O}\right), 78.1\left(\mathrm{C}_{\beta}\right), 110.7$, $111.1,111.6,112.2,112.3,115.9,120.1,120.8,122.3,123.4$, 127.6, 128.7, 146.9, 149.0, 149.1, 149.5, 149.9, 152.8, 197.6 $\left(\mathrm{C}_{\alpha}\right)$.

1-(4-(3,4-Dimethoxybenzyloxy)-3-methoxyphenyl)-2-(2-methoxyphenoxy)-1-propanol (3) ${ }^{1} \mathrm{H} \mathrm{NMR}\left(\mathrm{CDCl}_{3}\right) 1.18$ (d, $J=6.4$, $\left.3 \mathrm{H}, \mathrm{C}_{\gamma}-\mathrm{H}\right), 3.61\left(\mathrm{~s}, 1 \mathrm{H}, \mathrm{C}_{\alpha}-\mathrm{OH}\right), 3.88\left(\mathrm{~s}, 6 \mathrm{H},-\mathrm{OCH}_{3} \times 2\right), 3.89$ (s, $\left.6 \mathrm{H},-\mathrm{OCH}_{3} \times 2\right), 4.37\left(\mathrm{~m}, 1 \mathrm{H}, \mathrm{C}_{\beta}-\mathrm{H}\right), 4.83\left(\mathrm{~s}, 1 \mathrm{H}, \mathrm{C}_{\alpha}-\mathrm{H}\right), 5.06(\mathrm{~s}$,

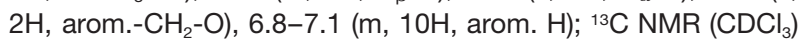
$13.5\left(\mathrm{C}_{\gamma}\right), 55.8,55.9,55.9,56.0\left(\mathrm{OCH}_{3}\right), 71.3\left(\operatorname{arom} .-\mathrm{CH}_{2}-\mathrm{O}\right), 73.6$ $\left(\mathrm{C}_{\beta}\right), 82.2\left(\mathrm{C}_{\alpha}\right), 110.0,110.8,111.0,112.1,114.0,118.4,119.4$, $120.1,121.1,123.4,129.8,133.2,146.7,147.3,148.7,149.1$, 149.6, 151.5; anal. calcd. for $\mathrm{C}_{26} \mathrm{H}_{30} \mathrm{O}_{7}$ : C 68.7, H 6.7; found: $\mathrm{C}$ 68.4, H 6.8 .

\section{Pyrolysis and product identification}

Pyrolysis was conducted with a Pyrex glass ampoule (length: $65 \mathrm{~mm}$, inner diameter: $4.0 \mathrm{~mm}$, glass thickness: $1.0 \mathrm{~mm})$. Model compound (0.65-0.98 $\left.\mathrm{mg}, 2.15 \times 10^{-3} \mathrm{mmol}\right)$ was added to a Pyrex glass tube as a $\mathrm{MeOH}$ solution, and then the solution was evaporated in vacuo in an upright setting. After exchanging the air inside the tube with $\mathrm{N}_{2}$, the ampoule was closed. Pyrolysis was conducted by inserting the whole ampoule into a muffle furnace preheated at a desired temperature between $250^{\circ} \mathrm{C}$ and $400^{\circ} \mathrm{C}$ for $2 \mathrm{~min}$. After pyrolysis, the ampoule was immediately taken out of the furnace and cooled with flowing air (30 s) and in cold water $(2 \mathrm{~min})$. Then, the ampoule was opened and the pyrolyzate was extracted with $5.0 \mathrm{ml}$ of $\mathrm{MeOH}$. The $\mathrm{MeOH}$ solution was subjected to the HPLC analysis for quantification of the 
unreacted model compound and the products by using phloroglucinol as an internal standard. Identification of the HPLC signals was conducted by comparing the retention times with those of the authentic compounds. Similar analyses were also conducted on TLC. Alternatively, the pyrolyzates were extracted with $\mathrm{CDCl}_{3}(1.0 \mathrm{ml})$ and the resulting solutions were analyzed with ${ }^{1} \mathrm{H}$ NMR. Product identification was also conducted with the NMR signals compared to the following data of the authentic compounds. Yields of the C-benzylated products were determined from the peak area of the ${ }^{1} \mathrm{H}$ NMR spectra.

Vanillin (4) ${ }^{1} \mathrm{H}$ NMR $\left(\mathrm{CDCl}_{3}\right) 3.96\left(\mathrm{~s}, 3 \mathrm{H},-\mathrm{OCH}_{3}\right), 6.23(\mathrm{~s}, 1 \mathrm{H}$, $\mathrm{OH}), 7.04(\mathrm{~d}, J=8.5,1 \mathrm{H}$, arom. $\mathrm{H}), 7.4-7.5(\mathrm{~m}, 2 \mathrm{H}$, arom. $\mathrm{H})$, 9.81 (s, $1 \mathrm{H}$, aldehyde $\mathrm{H})$.

Guaiacol (5) ${ }^{1} \mathrm{H}$ NMR $\left(\mathrm{CDCl}_{3}\right) 3.89\left(\mathrm{~s}, 3 \mathrm{H},-\mathrm{OCH}_{3}\right), 5.61(\mathrm{~s}, 1 \mathrm{H}$, $\mathrm{OH}), 6.8-7.0$ (m, 4H, arom. $\mathrm{H})$.

Veratraldehyde (6) ${ }^{1} \mathrm{H} \quad \mathrm{NMR}\left(\mathrm{CDCl}_{3}\right) 3.94,3.97(2 \mathrm{~s}, 6 \mathrm{H}$, $\left.-\mathrm{OCH}_{3} \times 2\right), 6.93(\mathrm{~d}, J=8.2,1 \mathrm{H}$, arom. $\mathrm{H}), 7.41(\mathrm{~d}, J=1.8,1 \mathrm{H}$, arom. H), 7.46 (dd, $J=1.8,8.2,1 \mathrm{H}$, arom. $\mathrm{H}$ ), 9.85 (s, $1 \mathrm{H}$, aldehyde $\mathrm{H}$ ).

1-(4-Hydroxy-3-methoxyphenyl)-1-propanone (7) ${ }^{1} \mathrm{H}$ NMR $\left(\mathrm{CDCl}_{3}\right) 1.22$ (t, $\left.J=7.3,3 \mathrm{H}, \mathrm{C}_{\gamma}-\mathrm{H}\right), 2.96\left(\mathrm{q}, J=7.3,2 \mathrm{H}, \mathrm{C}_{\beta}-\mathrm{H}\right)$, $3.96\left(\mathrm{~s}, 3 \mathrm{H},-\mathrm{OCH}_{3}\right), 6.04(\mathrm{~s}, 1 \mathrm{H}, \mathrm{OH}), 6.94(\mathrm{~d}, J=8.7,1 \mathrm{H}$, arom. $\mathrm{H}), 7.5-7.6(\mathrm{~m}, 2 \mathrm{H}$, arom. H).

3,4-Dimethoxytoluene (8) ${ }^{1} \mathrm{H}$ NMR $\left(\mathrm{CDCl}_{3}\right) 2.30(\mathrm{~s}, 1 \mathrm{H}$, arom. $\left.\mathrm{CH}_{3}\right), 3.85,3.87\left(2 \mathrm{~s}, 6 \mathrm{H},-\mathrm{OCH}_{3} \times 2\right), 6.7-6.9(\mathrm{~m}, 3 \mathrm{H}$, arom. H).

\section{1- (3- (3,4-Dimethoxybenzyl) -4-hydroxy-5-methoxyphenyl)-1-} propanone (9) $\mathrm{NaH}(60 \%$ in mineral oil, $8.4 \mathrm{mg}$ ) was added to a solution of compound $7(24.5 \mathrm{mg})$ in toluene $(1 \mathrm{ml})$, and the resulting solution was stirred at room temperature for $1 \mathrm{~h}$. Then, a solution of $\mathrm{Nal}(21 \mathrm{mg})$ and 3,4-dimethoxybenzyl bromide $(32.3 \mathrm{mg})$ in toluene $(0.5 \mathrm{ml})$ was added to the mixture and refluxed overnight. The reaction mixture was extracted with EtOAc and washed with brine, dried on anhydrous $\mathrm{Na}_{2} \mathrm{SO}_{4}$ and evaporated in vacuo. Preparative TLC (EtOAc/n-hexane $=1 / 2$, $\mathrm{v} / \mathrm{v}$ ) gave the C-benzylated compound $\mathbf{9}(\mathrm{Rf} 0.40,7.6 \mathrm{mg}$ ) along with the O-benzylated ( $\mathrm{Rf} 0.48,9.3 \mathrm{mg}$ ) and O,C-dibenzylated (Rf 0.35, $9.5 \mathrm{mg}$ ) compounds. Compound 9: ${ }^{1} \mathrm{H}$ NMR $\left(\mathrm{CDCl}_{3}\right)$ 1.18 (t, $J=7.2,3 \mathrm{H}, \mathrm{C}_{\gamma}-\mathrm{H}$ ), 2.89 (q, $J=7.2,2 \mathrm{H}, \mathrm{C}_{\beta}-\mathrm{H}$ ), 3.84, 3.85, $3.95\left(3 \mathrm{~s}, 9 \mathrm{H},-\mathrm{OCH}_{3} \times 3\right), 3.97$ (s, $2 \mathrm{H}$, arom. $-\mathrm{CH}_{2}$-arom.), 6.16 (s, $1 \mathrm{H}, \mathrm{OH}), 6.7-6.9(\mathrm{~m}, 3 \mathrm{H}$, arom. $\mathrm{H}), 7.40(\mathrm{~d}, J=1.7,1 \mathrm{H}$, arom. $\mathrm{H}), 7.43(\mathrm{~d}, J=1.7,1 \mathrm{H}$, arom. $\mathrm{H}) ;{ }^{13} \mathrm{C}$ NMR $\left(\mathrm{CDCl}_{3}\right) 8.5\left(\mathrm{C}_{\gamma}\right), 31.2$ $\left(\mathrm{C}_{\beta}\right), 35.1$ (arom. $-\mathrm{CH}_{2}$-arom.), 55.8, 55.9, $56.2\left(\mathrm{OCH}_{3}\right), 107.8$, $111.2,112.2,120.6,124.2,126.6,129.1,132.6,146.4,147.4$,

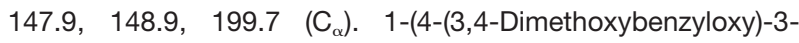
methoxyphenyl)-1-propanone: ${ }^{1} \mathrm{H}$ NMR $\left(\mathrm{CDCl}_{3}\right) 1.23(\mathrm{t}, J=7.3$, $3 \mathrm{H}, \mathrm{C}_{\gamma}-\mathrm{H}$ ), 2.95 (q, $\left.J=7.3,2 \mathrm{H}, \mathrm{C}_{\beta}-\mathrm{H}\right), 3.88,3.89,3.94(3 \mathrm{~s}, 9 \mathrm{H}$, $\left.-\mathrm{OCH}_{3} \times 3\right), 5.16\left(\mathrm{~s}, 1 \mathrm{H}\right.$, arom. $\left.-\mathrm{CH}_{2}-\mathrm{O}\right), 6.86(\mathrm{~d}, J=8.7,1 \mathrm{H}$, arom. H), $6.92(\mathrm{~d}, J=8.3,1 \mathrm{H}$, arom. H), 6.9-7.0 (m, 2H, arom. H), 7.52 (dd, $J=2.0,8.3,1 \mathrm{H}$, arom. H), $7.56(\mathrm{~d}, J=2.0,1 \mathrm{H}$, arom. $\mathrm{H}) ;{ }^{13} \mathrm{C}$ NMR $\left(\mathrm{CDCl}_{3}\right) 8.5\left(\mathrm{C}_{\gamma}\right), 31.3\left(\mathrm{C}_{\beta}\right), 55.9,55.9,56.0\left(\mathrm{OCH}_{3}\right), 70.9$ (arom.- $\mathrm{CH}_{2}-\mathrm{O}$ ), 110.5, 110.7, 111.1, 112.3, 120.0, 122.3, 128.8, 130.4, 149.0, 149.2, 149.5, 152.2, $199.6\left(\mathrm{C}_{\alpha}\right)$. 1-(3-(3,4-Dimethoxybenzyl) -4-(3,4-dimethoxybenzyloxy)-5-methoxyphenyl)-1propanone: ${ }^{1} \mathrm{H}$ NMR $\left(\mathrm{CDCl}_{3}\right) 1.22\left(\mathrm{t}, J=7.3,3 \mathrm{H}, \mathrm{C}_{\gamma}-\mathrm{H}\right), 2.90$ (q, $\left.J=7.3,2 \mathrm{H}, \mathrm{C}_{\beta}-\mathrm{H}\right), 3.76\left(\mathrm{~s}, 3 \mathrm{H},-\mathrm{OCH}_{3}\right), 3.84\left(\mathrm{~s}, 6 \mathrm{H},-\mathrm{OCH}_{3} \times 2\right)$, 3.88 (s, $5 \mathrm{H},-\mathrm{OCH}_{3}$, arom. $-\mathrm{CH}_{2}$-arom.), 3.96 (s, $\left.3 \mathrm{H},-\mathrm{OCH}_{3}\right), 4.94$ (s, $2 \mathrm{H}$, arom. $\left.-\mathrm{CH}_{2}-\mathrm{O}\right), 6.6-7.0(\mathrm{~m}, 6 \mathrm{H}$, arom. $\mathrm{H}), 7.34(\mathrm{~d}, J=2.0$, $1 \mathrm{H}$, arom. $\mathrm{H}), 7.48(\mathrm{~d}, J=2.0,1 \mathrm{H}$, arom. $\mathrm{H}) ;{ }^{13} \mathrm{C} \mathrm{NMR}\left(\mathrm{CDCl}_{3}\right) 8.4$ $\left(\mathrm{C}_{\gamma}\right), 31.5\left(\mathrm{C}_{\beta}\right)$, 35.8 (arom.- $\mathrm{CH}_{2}$-arom.), 55.7, 55.8, $55.9\left(\mathrm{OCH}_{3}\right)$, 74.6 (arom. $-\mathrm{CH}_{2}-\mathrm{O}$ ), 109.7, 110.8, 111.1, 111.6, 112.2, 120.7, $121.0,123.3,130.0,132.7,133.0,135.2,148.8,148.9,148.9$, $149.9,152.8,200.0\left(C_{\alpha}\right)$.
1-(3- (3,4-Dimethoxybenzyl) -4-hydroxy-5-methoxyphenyl)-1propene (10) Compound 10 was isolated from the pyrolyzate of trimer $3(0.98 \mathrm{mg} \times 20$ times) by PTLC (EtOAc/n-hexane = 1/2, v/v Rf 0.6, then $\left.\mathrm{CHCl}_{3} \mathrm{Rf} 0.7\right)$. ${ }^{1} \mathrm{H}$ NMR $\left(\mathrm{CDCl}_{3}\right) 1.89$ (dd, $\left.J=1.7,6.7,3 \mathrm{H}, \mathrm{C}_{\gamma}-\mathrm{H}\right), 3.84,3.84,3.89\left(3 \mathrm{~s}, 9 \mathrm{H},-\mathrm{OCH}_{3} \times 3\right), 3.91$ (s, $2 \mathrm{H}$, arom. $-\mathrm{CH}_{2}$-arom.), 5.66 (s, $\left.1 \mathrm{H}, \mathrm{OH}\right), 6.03$ (dq, $J=6.7$, 16.0, $\left.1 \mathrm{H}, \mathrm{C}_{\beta}-\mathrm{H}\right), 6.27\left(\mathrm{dq}, J=1.9,16.0,1 \mathrm{H}, \mathrm{C}_{\alpha}-\mathrm{H}\right), 6.6-6.9(\mathrm{~m}$, $5 \mathrm{H}$, arom. $\mathrm{H}$ ).

Isoeugenol (11) ${ }^{1} \mathrm{H}$ NMR $\left(\mathrm{CDCl}_{3}\right)$ trans isomer: 1.86 (dd, $\left.J=1.7,6.6,3 \mathrm{H}, \mathrm{C}_{\gamma}-\mathrm{H}\right), 3.89$ (s, 3H, $\left.-\mathrm{OCH}_{3}\right), 5.54(\mathrm{~s}, 1 \mathrm{H}, \mathrm{OH})$, 6.08 (dq, $J=6.6,13.2,1 \mathrm{H}, \mathrm{C}_{\beta}-\mathrm{H}$ ), 6.32 (dq, $J=1.7,13.2,1 \mathrm{H}$, $\left.\mathrm{C}_{\alpha}-\mathrm{H}\right), 6.8-7.10(\mathrm{~m}, 3 \mathrm{H}$, arom. $\mathrm{H})$.

1-(3,4-Dimethoxyphenyl)-1-propanone (12) ${ }^{1} \mathrm{H}$ NMR $\left(\mathrm{CDCl}_{3}\right)$ $1.21\left(\mathrm{t}, J=7.3,3 \mathrm{H}, \mathrm{C}_{\gamma}-\mathrm{H}\right.$ ), 2.97 (q, $J=7.3,2 \mathrm{H}, \mathrm{C}_{\beta}-\mathrm{H}$ ), 3.94, 3.95 $\left(2 \mathrm{~s}, 6 \mathrm{H},-\mathrm{OCH}_{3} \times 2\right), 6.89(\mathrm{~d}, J=8.4,1 \mathrm{H}$, arom. $\mathrm{H}), 7.55(\mathrm{~d}, J=1.9$, $1 \mathrm{H}$, arom. $\mathrm{H}$ ), 7.60 (dd, $J=1.9,8.4,1 \mathrm{H}$, arom. $\mathrm{H}$ ); ${ }^{13} \mathrm{C}$ NMR $\left(\mathrm{CDCl}_{3}\right)$ 8.6 $\left(\mathrm{C}_{\gamma}\right), 31.3\left(\mathrm{C}_{\beta}\right), 56.0,56.1\left(\mathrm{OCH}_{3}\right), 110.0,110.2$, 122.6, 130.2, 149.0, 153.1, $199.6\left(\mathrm{C}_{\alpha}\right)$.

4-O-Methyl isoeugenol (13) ${ }^{1} \mathrm{H} \mathrm{NMR}\left(\mathrm{CDCl}_{3}\right): 1.86$ (dd, $J=1.7$, 6.6, 3H, $\mathrm{C}_{\gamma}-\mathrm{H}$, trans), 1.91 (dd, J=1.8, 7.2, 3H, $\mathrm{C}_{\gamma}-\mathrm{H}, \mathrm{cis}$ ), 3.87, $3.89\left(2 \mathrm{~s}, 6 \mathrm{H},-\mathrm{OCH}_{3} \times 2\right.$, trans), 3.88, $3.89\left(2 \mathrm{~s}, 6 \mathrm{H},-\mathrm{OCH}_{3} \times 2\right.$, cis), 5.72 (dq, $\left.J=7.2,11.6,1 \mathrm{H}, \mathrm{C}_{\beta}-\mathrm{H}, \mathrm{cis}\right), 6.10$ (dq, $J=6.6,15.7$, $1 \mathrm{H}, \mathrm{C}_{\beta}-\mathrm{H}$, trans), 6.3-6.4 (m, $1 \mathrm{H}, \mathrm{C}_{\alpha}-\mathrm{H}$, trans cis $), 6.7-7.0$ $(\mathrm{m}, 3 \mathrm{H}$, arom. $\mathrm{H})$.

\section{Results and discussion}

\section{Characterization of the products}

Dimers 1 and 2 were almost quantitatively recovered in an open-top reactor (in $\mathrm{N}_{2} / 400^{\circ} \mathrm{C} / 2 \mathrm{~min}$ ). Contrary to this, $97.7 \%$ (1) and $52.9 \%$ (2) of these dimers were decomposed in a closed ampoule reactor under similar pyrolysis conditions. Trimer 3 was also almost completely decomposed in the closed ampoule reactor (in $\mathrm{N}_{2} / 400^{\circ} \mathrm{C} / 2 \mathrm{~min}$, recovery: $1.8 \%$ ).

Under this situation, the products obtained in the closed ampoule reactor are expected to be formed through the radical chain reactions. The chromatograms of the pyrolyzates are shown in Figure 2 (closed ampoule reactor $/ \mathrm{N}_{2} / 400^{\circ} \mathrm{C} / 2 \mathrm{~min}$ ). Formation of guaiacol (5, $57.0 \mathrm{~mol} \%$ from 1, $9.8 \mathrm{~mol} \%$ from 2, $62.7 \mathrm{~mol} \%$ from 3 ) indicates the cleavage of the $\beta$-ether bonds. As shown in the chromatogram from dimer $\mathbf{1}$, isoeugenol $(\mathbf{1 1}, 19.6$ mol\%), 1-(4-hydroxy-3-methoxyphenyl)-1-propanone (7, $4.2 \mathrm{~mol} \%)$ and vanillin $(4,2.3 \mathrm{~mol} \%)$ were identified as the decomposed products of dimer 1 . The non-phenolic dimer 2 also gave similar types of the products, 4-O-methyl isoeugenol (13, $2.8 \mathrm{~mol} \%), 1-3,4$-dimethoxyphenyl-1-propanone $(12,6.8 \mathrm{~mol} \%)$ and veratraldehyde (6, $4.9 \mathrm{~mol} \%$ ), although their yields are comparatively low. Consequently, $\mathrm{C}_{\alpha}=\mathrm{C}_{\beta}\left(11\right.$ and 13) and $\mathrm{C}_{\alpha}=\mathrm{O}(7$ and 12) types of structures are formed after cleavage of the $\mathrm{C}_{\beta}-\mathrm{O}$ bond. The reactions to form aldehyde-type compounds (4 and 6) also lead to the depolymerization of lignin macromolecules.

The chromatogram of trimer $\mathbf{3}$ is more complicated (Figure 2). From the comparison with the authentic compounds, the dimer 1-derived products [vanillin (4, $0.9 \mathrm{~mol} \%), \mathrm{C}_{\alpha}=\mathrm{O}$ type 7 (9.0 mol\%) and isoeugenol (11, $12.1 \mathrm{~mol} \%)]$ were identified with a certain amount 


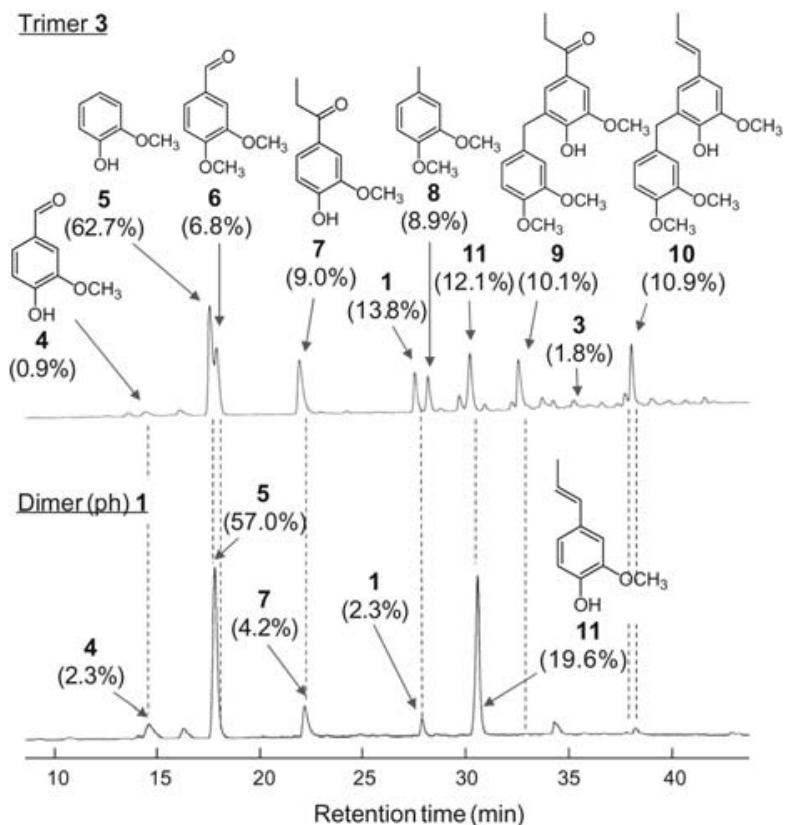

Dimer(non-ph) 2

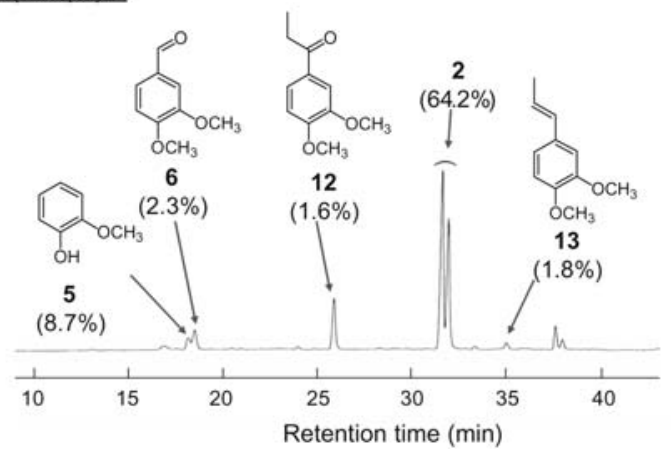

Figure 2 High performance liquid chromatograms of the pyrolysis mixtures from dimer 1 and 2 and trimer $3\left(\mathrm{~N}_{2} / 400^{\circ} \mathrm{C} / 2 \mathrm{~min}\right)$.

(13.8 mol\%) of dimer $\mathbf{1}$. Accordingly, dimer $\mathbf{1}$ is an important intermediate in pyrolysis of trimer 3 . Some of the phenoxy radical formed through homolysis of the $\alpha$-ether bond is stabilized as dimer $\mathbf{1}$ by abstracting hydrogen from other compounds.

3,4-Dimethoxytoluene (8, $8.9 \mathrm{~mol} \%)$ and 3,4-dimethoxybenzaldehyde $(6,6.8 \mathrm{~mol} \%)$ were obtained as the fragmentation products of the $\alpha$-ether bond in trimer 3 . Homolysis of the $\alpha$-ether bond yields the benzyl radical intermediate, and this is converted to compound $\mathbf{8}$ (through $\mathrm{H}$-abstraction) and compound 6 (through coupling with $\mathrm{OH}$ radical and subsequent oxidation). Formation of these products indicates the radical-induced reactions, such as $\mathrm{H}$-abstraction and radical coupling occurring in pyrolysis of trimer 3 . It is also noted that $\mathrm{OH}$ radical exists during pyrolysis. Dehydroxylation at $\mathrm{C}_{\alpha}-\mathrm{OH}$ would be a source of $\mathrm{OH}$ radical, as described later.

Relating to the identification of the two peaks at 32.5 and $38.0 \mathrm{~min}$, the enlarged ${ }^{1} \mathrm{H}$ NMR spectra of the pyrolyzate of trimer $\mathbf{3}$ are shown in Figure 3, compared to those of the pyrolyzate of dimer 1 . Double doublets of the $\mathrm{C}_{\gamma}$-protons of isoeugenol (cis: $1.90 \mathrm{ppm}, \mathrm{dd}, J=1.9$, $7.2 \mathrm{~Hz}$; trans: $1.86 \mathrm{ppm}, \mathrm{dd}, J=1.7,6.6 \mathrm{~Hz}$ ) were observed in both spectra. In addition, a similar double

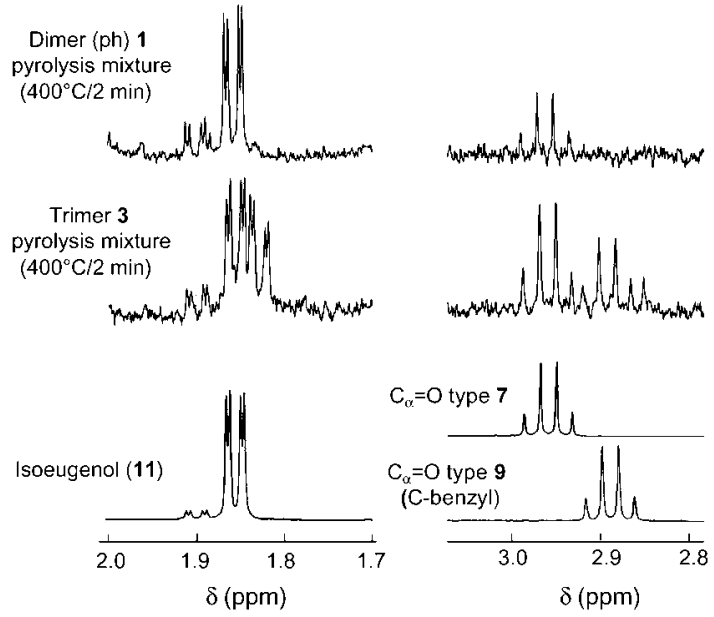

Figure $3{ }^{1} \mathrm{H}$ NMR spectra of the pyrolysis mixtures from phenolic dimer 1 and trimer 3 and reference compounds $\left(\mathrm{N}_{2} / 400^{\circ} \mathrm{C} /\right.$ $2 \mathrm{~min})$.

doublet $(J=1.7,6.9 \mathrm{~Hz})$ was observed in the spectra (trimer 3) at a slightly higher magnetic field of $1.83 \mathrm{ppm}$. Similarly, a quartet $(2.89 \mathrm{ppm}, J=7.3 \mathrm{~Hz})$ was observed in a slightly higher magnetic field than that $(2.96 \mathrm{ppm}$, $J=7.3 \mathrm{~Hz}$ ) of the $\mathrm{C}_{\beta}$-protons of compound 7 in the spectrum (trimer 3 ). From the ${ }^{1} \mathrm{H}$ NMR spectra of the isolated compounds, these compounds were expected to be 3,4dimethoxybenzyl derivatives 9 and 10. To confirm the structures, benzylation with 3,4-dimethoxybenzyl bromide under the conditions of $\mathrm{NaH} / \mathrm{Nal} /$ toluene/reflux (Elkobaisi and Hichinbottom 1958) was conducted for compounds 7 and 11. Benzylation of compound 7 gave 1-(3-(3,4-dimethoxybenzyl)-4-hydroxy-5-methoxyphenyl)-1-propanone (9) as a C-benzylated product, along with the O-benzylated and O-, C-dibenzylated derivatives. Although preparation of the C-benzylated isoeugenol was not successful under similar conditions, structure of compound $\mathbf{1 0}$ was tentatively presented as 1-(3-(3,4-dimethoxybenzyl)-4-hydroxy-5-methoxyphenyl) -1-propene from the ${ }^{1} \mathrm{H}$ NMR spectrum of the isolated compound. These C-benzylated products (9: $10.1 \mathrm{~mol} \%$, 10: $10.9 \mathrm{~mol} \%)$ are formed by recombination of the phenoxy and benzyl radicals which are produced by homolysis of the $\mathrm{C}_{\beta}-\mathrm{O}$ bond.

\section{Radical chain reactions}

Formation of the $\mathrm{C}_{\alpha}=\mathrm{C}_{\beta}$ and $\mathrm{C}_{\alpha}=\mathrm{O}$ structures can be explained with the proposed pathways (Figure 4) which start from the $\mathrm{H}$-abstraction at the phenolic $\mathrm{O}-\mathrm{H}$ and $\mathrm{C}_{\alpha}-\mathrm{H}$, respectively. The phenolic $\mathrm{O}-\mathrm{H}$ and $\mathrm{C}_{\alpha}-\mathrm{H}$ bonds, which have relatively low calculated BDE (Figure 5), tend to be cleaved in the presence of radical species (radical initiators).

$\mathrm{H}$-abstraction occurring at the $\mathrm{C}_{\alpha}-\underline{H}$ (pathway a) forms a benzyl $\left(C_{\alpha}\right)$ radical. The following cleavage of the $C_{\beta}-O$ bond ( $\beta$-scission reaction) gives guaiacyl radical and enol which further isomerizes to the $\mathrm{C}_{\alpha}=\mathrm{O}$ type structure (compounds 7 and 12). Similar $\beta$-scission reactions are reported for phenethyl-phenyl ether (Autrey et al. 1991; Britt et al. 1995; Beste et al. 2007) and $\alpha, \beta$-diether-type trimers (Kawamoto et al. 2008a), in which both side chain $\mathrm{C}_{\alpha}-\mathrm{OH}$ and $\mathrm{C}_{\beta}-\mathrm{OH}$ are etherified. Homolysis of the $\mathrm{C}_{\alpha}-\mathrm{O}$ 

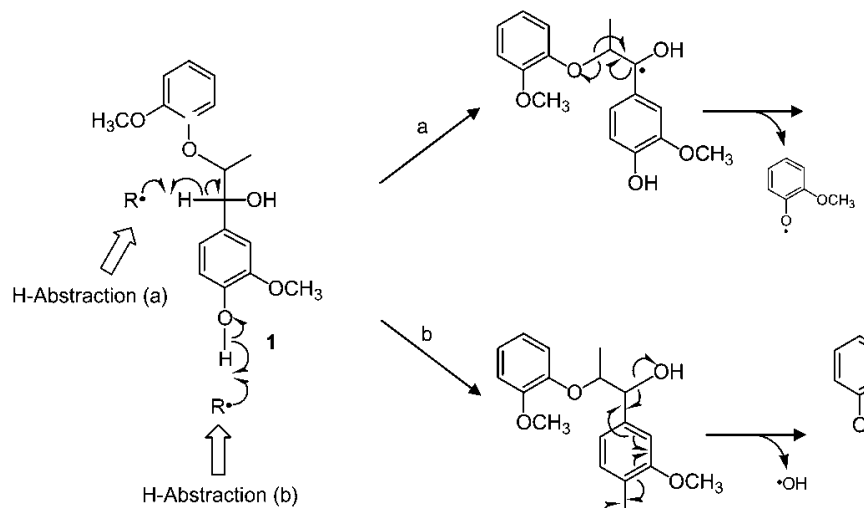<smiles>C/C=C(\O)c1ccc(O)c(OC)c1</smiles><smiles>CCC(=O)c1ccc(O)c(OC)c1</smiles>

$\mathrm{C}_{\alpha}=\mathrm{O}$ type 7

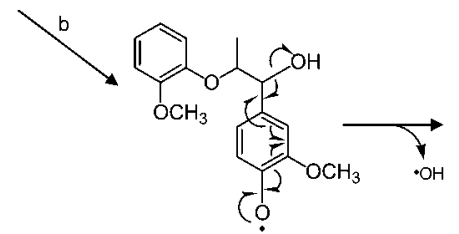

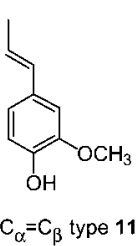

Figure 4 Proposed formation mechanisms of the $\mathrm{C}_{\alpha}=\mathrm{O}$ and $\mathrm{C}_{\alpha}=\mathrm{C}_{\beta}$ types of products from phenolic dimer 1 through different $\mathrm{H}$-abstraction reactions.

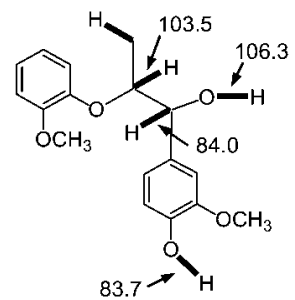

Figure 5 Calculated BDEs (kcal/mol) for various $\mathrm{C}-\mathrm{H}$ and $\mathrm{O}-\mathrm{H}$ bonds (AM1, B3LYP/6-311G*). The BDE values do not include zero-point energy.

bonds in the latter trimers forms $\mathrm{C}_{\alpha}$ radical intermediates, and then cleavage of the $\mathrm{C}_{\beta}-\mathrm{O}$ bond occurs.

The $\mathrm{C}_{\alpha}=\mathrm{C}_{\beta}$ type products (compounds 11 and 13) can be produced through $\mathrm{H}$-abstraction at the phenolic $\mathrm{O}-\underline{\mathrm{H}}$ (pathway b). The resulting phenoxy radical would form quinone methide via the $\beta$-scission-type reaction with releasing hydroxyl radical from $\mathrm{C}_{\alpha}-\mathrm{OH}$. Then, homolysis of the $\mathrm{C}_{\beta}-\mathrm{O}$ bond occurs more easily in the quinone methide form as reported in the literature (Kawamoto et al. 2008a) and gives the $\mathrm{C}_{\alpha}=\mathrm{C}_{\beta}$ type structure and guaiacyl radical. Lower $\mathrm{BDE}$ of the $\mathrm{C}_{\beta}-\mathrm{O}$ bond in quinone methide form than that of the phenolic form is reported from the theoretical calculation (Ponomarev 1997). This quinone methide formation from phenoxy radical is a key step in pathway b. Although further study is necessary to confirm this, the previous observation supports this reaction; the cleavage mode of the $\alpha$-ether linkages in phenolic model compounds changed from heterolysis to homolysis in the presence of radical species (Kawamoto et al. 2008a). Existence of $\mathrm{OH}$ radical in pyrolysis of trimer $\mathbf{3}$ as discussed earlier also supports this radical quinone methide formation.

The $\mathrm{C}_{\alpha}=\mathrm{C}_{\beta}$ type product can also be formed from the $\mathrm{C}_{\beta}$. which is formed through direct homolysis of the $\mathrm{C}_{\beta}$ $\mathrm{O}$ bond. Dimer 2 probably forms 4-O-methyl isoeugenol (13) in this route. Lower yield of compound $\mathbf{1 3}$ arises from the difficulty in formation of the quinone methide type intermediate from non-phenolic dimer 2.

As for the aldehyde-type products (compounds 4 and 6), Faix et al. (1988) have reported the formation of vanillin benzyl ether from a trimer with the $C_{\alpha}=0$ type side chain, $\omega$-guaiacyl-acetoguaiacone-benzyl ether, even at a lower temperature of $240^{\circ} \mathrm{C}$, although the formation mechanism has not been discussed. Accordingly, the aldehyde-type compounds are expected if the $\mathrm{C}_{\alpha}-\mathrm{OH}$ is oxidized to the $\mathrm{C}_{\alpha}=\mathrm{O}$ structure. This oxidation is also possible from the $\mathrm{C}_{\alpha}$. intermediate, although the $\mathrm{C}_{\alpha}=\mathrm{O}$ type dimers and trimer were not detected in this study. These $\mathrm{C}_{\alpha}=\mathrm{O}$ type compounds may be unstable under the present pyrolysis conditions.

\section{Different reactivities of phenolic and non-phenolic dimers}

Figure 6 shows the temperature-dependency in pyrolysis of dimers $\mathbf{1}$ and $\mathbf{2}$. As indicated in the literature (Kawamoto et al. 2008b), phenolic dimer $\mathbf{1}$ is much more

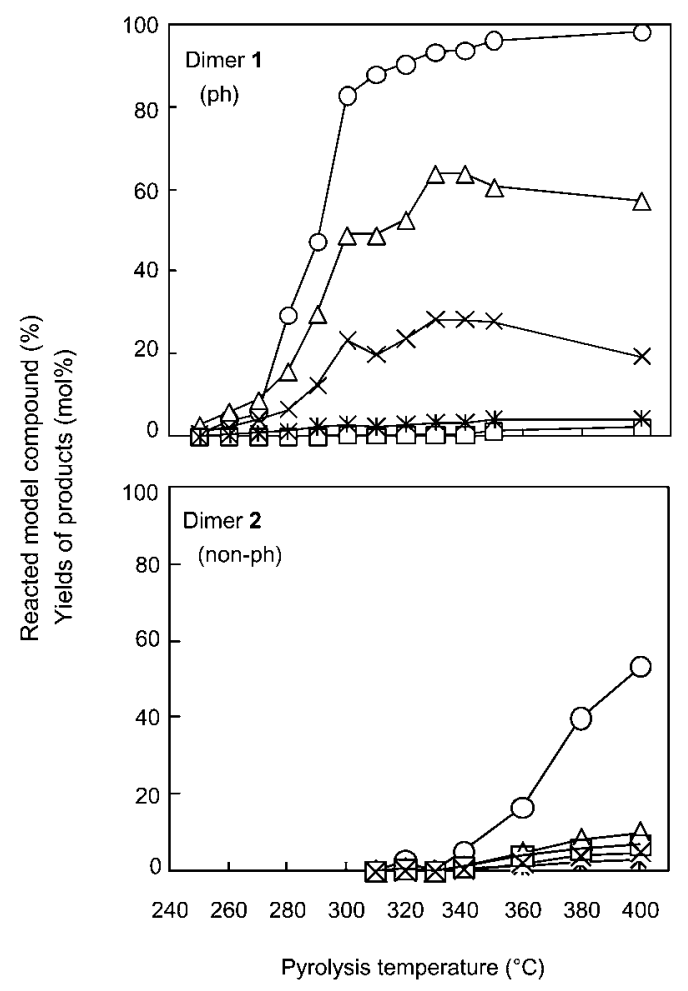

Figure 6 Influences of the pyrolysis temperature on the reactivities of dimers 1 and $2\left(\mathrm{~N}_{2} / 2 \mathrm{~min}\right)$. $\bigcirc$ : reacted dimer 1 or $\mathbf{2}, \Delta$ : guaiacol (5), $X: \mathrm{C}_{\alpha}=\mathrm{C}_{\beta}$ (11 or 13$), *: \mathrm{C}_{\alpha}=\mathrm{O}(\mathbf{7}$ or 12$), \square$ : aldehyde (4 or 6$)$. 
reactive than the methylated (non-phenolic) dimer 2. Pyrolysis reactions of dimer $\mathbf{1}$ started at around $260^{\circ} \mathrm{C}$ and became very reactive at above $300^{\circ} \mathrm{C}$. Isoeugenol $\left(\mathrm{C}_{\alpha}=\mathrm{C}_{\beta}\right.$ type $)$ was usually obtained predominantly instead of the $\mathrm{C}_{\alpha}=\mathrm{O}$ type 7 and aldehyde-type 4. Consequently, pathway b (Figure 4) is important in the ether cleavage of the phenolic dimer.

Contrary to this, pyrolysis of non-phenolic dimer 2 started at a higher temperature at around $350^{\circ} \mathrm{C}$ and was not so effective even at $400^{\circ} \mathrm{C}$. Furthermore, the guaiacol yield which shows the tendency of the $\beta$-ether cleavage is also low. Some of the $\beta$-ether linkages are cleaved mainly via pathway a (Figure 4) as indicated by the formation of the $\mathrm{C}_{\alpha}=\mathrm{O}$ type product 12 .

Different reactivities between the phenolic and nonphenolic dimers can be explained by the different number of radical species formed from pathways $a$ and $b$ (Figure 4). Pathway a gives guaiacyl radical as a sole radical product by consuming one radical in the $\mathrm{H}$ abstraction step. Recombination is also possible as a termination step. Accordingly, it is difficult to sustain the radical chain reaction only with pathway a. Alternatively, pathway $b$, which gives three radical species, i.e., hydroxyl, guaiacyl and isoeugenol radicals, increases radical concentration greatly. This makes the radical chain reaction sustainable even with the influence of the termination reactions, such as recombination.

\section{Role of $\mathrm{C}_{\alpha}-\mathrm{O}$ bond homolysis in pyrolysis of trimer 3}

Reactivity of trimer $\mathbf{3}$ was between the phenolic and nonphenolic dimers as shown in Figure 7. Homolysis of the $\alpha$-ether linkage to form dimer phenoxy and benzyl radicals serves as a source of radical species for initiation of the chain reaction (Figure 8). The reactivity increased at $300-350^{\circ} \mathrm{C}$, and this temperature range is close to those reported for the homolysis of the $\alpha$-ether linkages in dimers. Homolysis of the $\alpha$-ether linkage occurring at this temperature range is also supported by the formation of compounds $\mathbf{6}$ and 8.

The C-benzylated $\mathrm{C}_{\alpha}=\mathrm{O}$ type compound 9 was formed selectively at $310-350^{\circ} \mathrm{C}$ as a $\mathrm{C}_{\beta}-\mathrm{O}$ bond cleaved

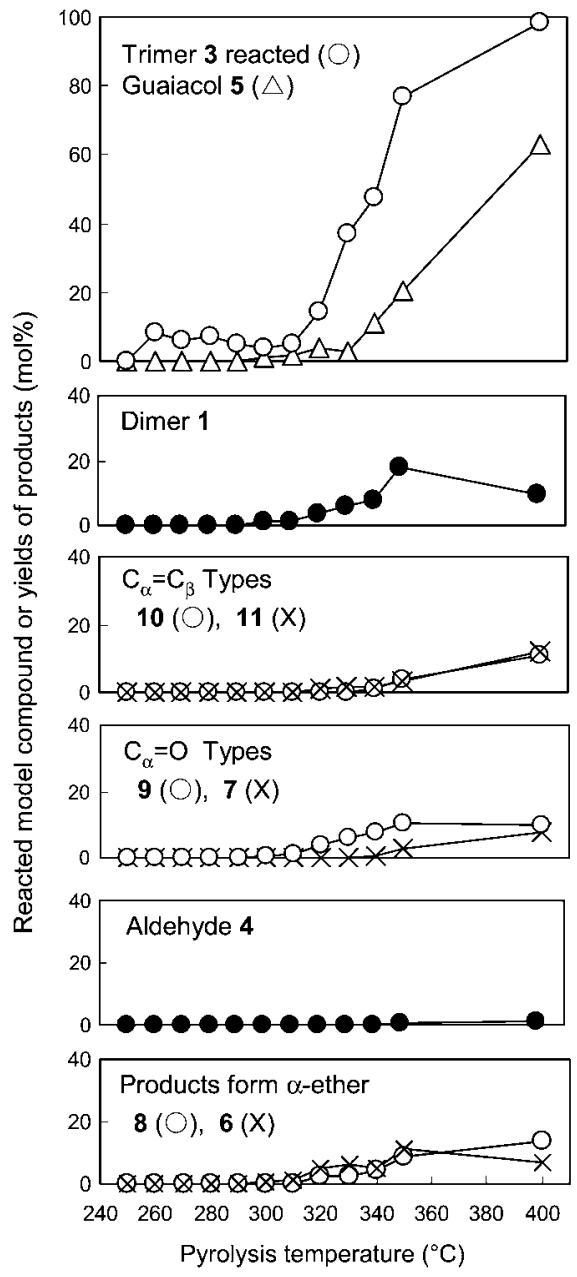

Figure 7 Influence of the pyrolysis temperature on the reactivity of trimer $3\left(\mathrm{~N}_{2} / 2 \mathrm{~min}\right)$.

product (Figure 7). This indicates that $\mathrm{H}$-abstraction at $\mathrm{C}_{\alpha}-\mathrm{H}$ (pathway a in Figure 4) predominantly occurs at this early pyrolysis stage. Low concentration of the phenolic hydroxyl group makes this reaction more effective. With increasing temperature, concentration of dimer $\mathbf{1}$ increases, and pathways a and b become competitive.

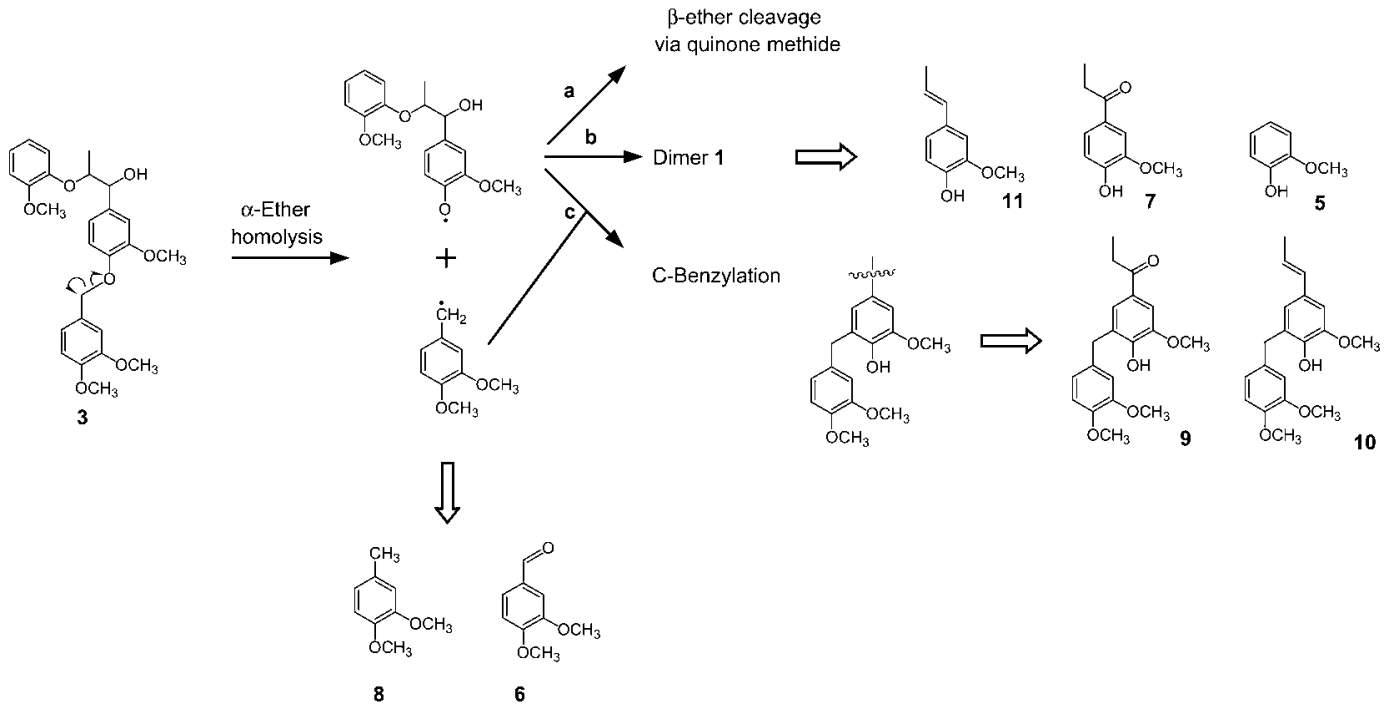

Figure 8 Role of the homolysis of the $\alpha$-ether linkage in pyrolysis of trimer 3. 
The yield of aldehyde-type compound $\mathbf{4}$ was always lower than those of the products from pathways a and $\mathrm{b}$.

Nakamura et al. (2008) have demonstrated that depolymerization of Japanese cedar MWL occurs mainly at $300-350^{\circ} \mathrm{C}$, and this temperature range is lower than that of the cleavage of the $\mathrm{C}_{\beta}-\mathrm{O}$ bond in non-phenolic dimer. From the similarity of the depolymerization (via ether cleavage) temperature between MWL and non-phenolic $\alpha$-ether type dimer, the authors reported that homolytic cleavage of the $\alpha$-ether linkages in lignin structures obtained by endwise polymerization accelerates the depolymerization.

Another explanation is chain depolymerization via phenoxy radicals as the terminal units in endwise polymerisates of lignin. However, the dimer phenoxy radical tends to be stabilized as dimer $\mathbf{1}$ and $\mathrm{C}$-benzylated product (pathways b and c, Figure 10) instead of proceeding to the $\beta$-ether cleavage to form isoeugenol and guaiacol (pathway a). These experimental facts indicate that lower temperature homolysis of the $\alpha$-ether linkages (not the terminal units) serves a radical source for further depolymerization (via ether cleavages) as part of the radical chain reactions reported in this paper.

\section{Conclusions}

$\beta$-Ether-type dimers and an $\alpha, \beta$-diether-type trimer were pyrolyzed in a sealed reactor $\left(\mathrm{N}_{2} / 400^{\circ} \mathrm{C} / 2 \mathrm{~min}\right)$. The product analysis revealed the radical chain depolymerization (ether cleavage) pathways which are initiated from the $\mathrm{H}$ abstraction at the phenolic $\mathrm{O}-\underline{H}$ and $\mathrm{C}_{\alpha}-\underline{H}$. The former pathway was more effective (and sustainable) even at the lower pyrolysis temperature, because this pathway increases radical concentration by forming three radical species. Higher reactivity of the phenolic dimer can be explained with this character. In pyrolysis of the trimer, homolysis of the $\alpha$-ether linkage (occurring at 300$350^{\circ} \mathrm{C}$ ) served as a radical source for initiating the chain reactions.

\section{Acknowledgements}

This research was supported by a Grant-in-Aid for Scientific Research (C)(2) (No. 18580163, 2006.4-2008.3) and the 21st COE program "Establishment of Sustainable Energy System" from the Ministry of Education, Culture, Sports, Science and Technology, Japan.

\section{References}

Autrey, S.T., Alnajjar, M.S., Nelson, D.A., Franz, J.A. (1991) Absolute rate constants for $\beta$-scission reaction of the 1-phenyl-2- phenoxypropyl radical: a model for radical reactions of lignin. J. Org. Chem. 56:2197-2202.

Beste, A., Buchanan III, A.C., Britt, P.F., Hathorn, B.C., Harrison, R.J. (2007) Kinetic analysis of the pyrolysis of phenethyl phenyl ether: computational prediction of $\alpha / \beta$-selectivities. J. Phys. Chem. 111:12118-12126.

Brežný, R., Mihálov, V., Kováčik, V. (1983) Low temperature thermolysis of lignins. I. Reactions of $\beta-O-4$ model compounds. Holzforschung 37:199-204.

Brežný, R., Šurina, I., Kováčik, V. (1984) Low temperature thermolysis of lignins. II. Thermofractography and thermal analysis of $\beta-O-4$ model compounds. Holzforschung 38:19-24.

Britt, P.F., Buchanan III, A.C., Malcolm, E.A. (1995) Thermolysis of phenethyl phenyl ether: a model for ether linkages in lignin and low rank coal. J. Org. Chem. 60:6523-6536.

Elkobaisi, F.M., Hichinbottom, W.J. (1958) C-Benzylation of phenols by used of sodium hydride. J. Chem. Soc. 2431-2432.

Faix, O., Meier, D., Fortmann, I. (1988) Pyrolysis-gas chromatography-mass spectrometry of two trimeric lignin model compounds with alkyl-aryl ether structure. J. Anal. Appl. Pyrol. 14:135-148.

Fenner, R.A., Lephardt, J.O. (1981) Examination of the thermal decomposition of Kraft pine lignin by Fourier transform infrared evolved gas analysis. J. Agric. Food Chem. 29:846-849.

Gardner, D.J., Schultz, T.P., McGinnis, G.D. (1985) The pyrolytic behavior of selected lignin preparations. J. Wood Chem. Technol. 5:85-110.

Haw, J.F., Schultz, T.P. (1985) Carbon-13 CP/MAS NMR and FTIR study of low-temperature lignin pyrolysis. Holzforschung 39:289-296.

Jakab, E., Faix, O., Till, F. (1997) Thermal decomposition of milled wood lignins studied by thermogravimetry/mass spectrometry. J. Anal. Appl. Pyrol. 40-41:171-186.

Kawamoto, H., Saka, S. (2007) Role of side-chain hydroxyl groups in pyrolytic reaction of phenolic $\beta$-ether type of lignin dimer. J. Wood Chem. Technol. 27:113-120.

Kawamoto, H., Horigoshi, S., Saka, S. (2007a) Pyrolysis reactions of various lignin model dimers. J. Wood Sci. 53:168174.

Kawamoto, H., Horigoshi, S., Saka, S. (2007b) Effects of sidechain hydroxyl groups on pyrolytic $\beta$-ether cleavage of phenolic lignin model dimer. J. Wood Sci. 53:268-271.

Kawamoto, H., Nakamura, T., Saka, S. (2008a) Pyrolytic cleavage mechanisms of lignin-ether linkages: a study on $p$-substituted dimers and trimers. Holzforschung 62:50-56.

Kawamoto, H., Ryoritani, M., Saka, S. (2008b) Different pyrolytic cleavage mechanisms of $\beta$-ether bond depending on the side-chain structure of lignin dimers. J. Anal. Appl. Pyrol. 81:88-94.

Klein, M.T., Virk, P.S. (1983) Model pathways in lignin thermolysis. 1. Phenethyl phenyl ether. Ind. Eng. Chem. Fundam. 22:35-45.

Nakamura, T., Kawamoto, H., Saka, S. (2008) Pyrolysis behavior of Japanese cedar wood lignin studied with various model dimers. J. Anal. Appl. Pyrol. 81:173-182.

Ponomarev, D.A. (1997) Formation of quinone methides: an alternative pathway to thermal degradation of some $\beta-O-4-$ ether as compounds modeling lignin. Russian J. Appl. Chem. 70:824-826.

Received November 12, 2008. Accepted February 16, 2009. Previously published online May 7, 2009. 